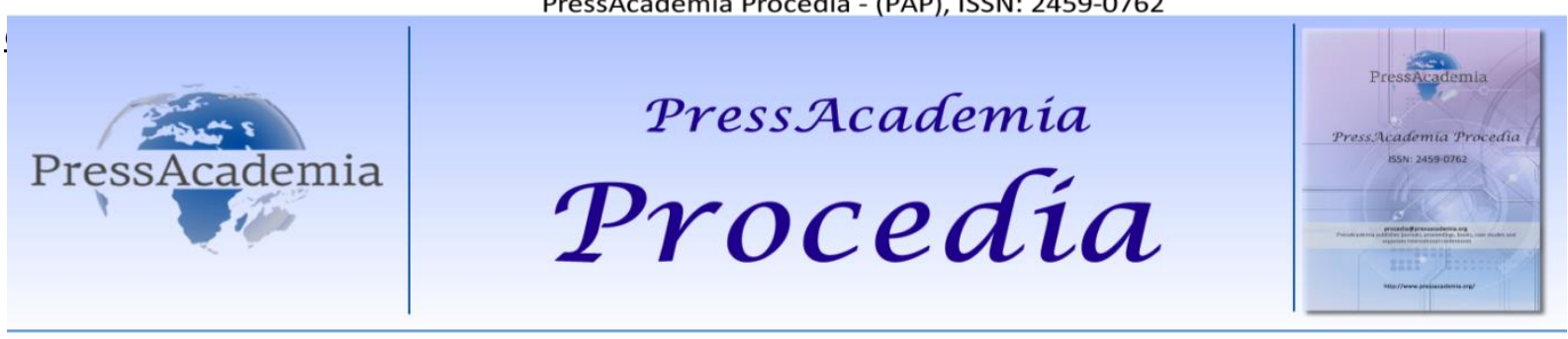

Global Business Research Congress (GBRC), May 24-25, 2017, Istanbul, Turkey.

\title{
CHANGES BROUGHT BY THE LAW ON HUMAN RIGHTS AND EQUALITY INSTITUTION OF TURKEY
}

\author{
DOI: 10.17261/Pressacademia.2017.419 \\ PAP-GBRC-V.3-2017(34)-p.350-357
}

\section{Başak Güneş}

İstanbul Technical University, Macka Campus, 34367 Maçka/Beşiktaş, İstanbul, Turkey. basakgunes.bg@gmail.com

To cite this document

Güneş,B , (2017). Changes brought by the law on human rights and equality institution of Turkey. PressAcademia Procedia (PAP), V.3, p.350-357

Permemant link to this document: http://doi.org/10.17261/Pressacademia.2017.419

Copyright: Published by PressAcademia and limited licenced re-use rights only.

\begin{abstract}
On 20/04/2016, the Law No. 6701 on Human Rights and Equality Institution of Turkey entered into force. Although it seems like a law of association due to its name, the law essentially includes the conceptual definitions of discrimination and the prevention of discrimination as well as the formation, duties and authorities of the Human Rights and Equality Institution. In this regard, the first two chapters of the Act contain the purpose and scope, definitions, equality principle and prohibition of discrimination, the scope of the discrimination law, types of discrimination, discrimination law in employment and self-employment and the cases which cannot be considered as discrimination. In other sections; the establishment, structure, duties, personnel regime of the Human Rights and Equality Institution of Turkey, application to the institution and its reviewing procedures are covered. The law is open to criticism in many ways. According to Article 3 of the Law, discrimination based on gender, race, color, language, religion, belief, sect, philosophical and political opinion, ethnicity, wealth, birth and marital status is prohibited. It is understood that there are only a limited number of issues to be considered as the basis for discrimination in the matter, since there is no such phrase as "et cetera" in the ruling. According to Article 17 of the Law, any natural or legal person who claims to be harmed by the violation of the discrimination law may apply to the Human Rights and Equality Institution established under the Law No. 6701. However, in case of discrimination other than discrimination based on Article 3, it is a question that it can not apply to the Institution. Furthermore, before applying to the Institution, it is stipulated that the persons should request from the relevant party to correct the application which they claim is contrary to this Law. Stipulating such a condition in the examination of individual applications, which is the fundamental activity to keep the institution functioning, will make it difficult for the individual to apply to the institution, especially if the discrimination is carried out by someone who has a hierarchical relationship with the individual. When the Human Rights and Equality Institution detects discrimination, the sanction imposed is administrative penalty. However, the minimum amount of administrative penalties defined by Law is quite low. There is also the authority of the Institution to convert this penalty to a penalty of warning. It is therefore difficult to argue, that a deterrent sanction mechanism is stipulated in the Law.
\end{abstract}

Keywords: Human rights and equality institution of Turkey, definition of discrimination, equality principle, prohibition of discrimination, the Law No. 6701 on Human Rights and Equality Institution of Turkey.

JEL Codes: K30, K31

\section{TÜRKIYE INSAN HAKLARI VE EŞiTLIK KURUMU KANUNU ILE GETIRILEN YENILIKLER}

\section{ÖZET}

20.04.2016 tarihinde 6701 sayılı Türkiye İnsan Hakları ve Eşitlik Kurumu Kanunu yürürlüğe girmiştir. Her ne kadar isminden ötürü bir teşkilat kanunu gibi görünse de, Kanun esasen İnsan Hakları ve Eşitlik Kurumu'nun oluşumu, göreve ve yetkilerinin yanı sıra ayrımcılığa ilişkin kavramsal tanımlar ve ayrımcılığın önlenmesine ilişkin düzenlemeler de içermektedir. Bu doğrultuda, Kanun'un ilk iki bölümünde amaç ve kapsam, tanımlar, eşitlik ilkesi ve ayrımcılık yasağı, ayrımcılık yasağının kapsamı, ayrımcılık türleri, istihdamda ve serbest meslekte ayrımcılık yasağı ile ayrımcılığı ileri sürülemeyeceği hallere yer verilmiştir. Diğer bölümlerde ise, Türkiye İnsan Hakları ve Eşitlik Kurumu'nun kuruluşu, teşkilat yapısı, görevleri, personel rejimi, Kuruma başvuru ve Kurumun inceleme usulleri ile yaptırımlar ele alınmaktadır. Kanun pek çok açıdan eleştiriye açıktır. Öncelikle Kanun'un 3. maddesine göre, bu Kanun kapsamında cinsiyet, ırk, renk, dil, din, inanç, mezhep, felsefi ve siyasi görüş, etnik köken, servet, doğum, medeni hâl, sağlık durumu, engellilik ve yaş temellerine dayalı ayrımcılık yasaktır. Söz konusu hükümde "ve benzeri" gibi bir ibareye yer verilmediği için maddede ayrımcılığa temel teşkil etmek üzere sayılan hususların sınırlı sayıda olduğu anlaşılmaktadır. Kanun'un 17. maddesine göre, ayrımcılık yasağı ihlalinden zarar gördüğü iddiasında bulunan her gerçek ve tüzel kişi 6701 sayılı Kanun çerçevesinde oluşturulan İnsan Hakları ve Eşitlik Kurumu'na başvurabilir. Ancak 3. maddede sayılan ayrımcılık temelleri dışındaki ayrımcılık hallerinde, Kuruma başvurup başvuramayacağı soru işaretidir. Ayrıca Kuruma başvurmadan önce, kişilerin, bu Kanun'a 
aykırı olduğunu iddia ettikleri uygulamanın düzeltilmesini ilgili taraftan talep etmesi gerektiği hükme bağlanmıştır. Kurumu gerçekten işlevsel kılacak temel faaliyet olan bireysel başvuruların incelenmesinde böyle bir koşulun öngörülmesi, özellikle ayrımcılığın ilgilinin hiyerarşik ilişki içerisinde bulunduğu biri tarafından gerçekleştirilmesi halinde Kuruma başvurmasını zorlaştıracaktır.

Insan Hakları ve Eşitlik Kurumu'nun ayrımcılık yapıldığını tespit etmesi halinde uygulayacağı yaptırım idari para cezasıdır; ancak Kanun'da idari para cezalarının asgari miktarı oldukça düşük belirlenmiştir. Ayrıca Kurumun söz konusu cezayı uyarı cezasına dönüştürme yetkisi de mevcuttur. Dolayısıyla Kanun'da caydırıcı bir yaptırım mekanizması öngörüldüğünü ileri sürmek güçtür. On 20/04/2016, the Law No. 6701 on Human Rights and Equality Institution of Turkey entered into force. Although it seems like a law of association due to its name, the law essentially includes the conceptual definitions of discrimination and the prevention of discrimination as well as the formation, duties and authorities of the Human Rights and Equality Institution. In this regard, the first two chapters of the Act contain the purpose and scope, definitions, equality principle and prohibition of discrimination, the scope of the discrimination law, types of discrimination, discrimination law in employment and self-employment and the cases which cannot be considered as discrimination. In other sections; the establishment, structure, duties, personnel regime of the Human Rights and Equality Institution of Turkey, application to the institution and its reviewing procedures are covered.The law is open to criticism in many ways. According to Article 3 of the Law, discrimination based on gender, race, color, language, religion, belief, sect, philosophical and political opinion, ethnicity, wealth, birth and marital status is prohibited. It is understood that there are only a limited number of issues to be considered as the basis for discrimination in the matter, since there is no such phrase as "et cetera" in the ruling. According to Article 17 of the Law, any natural or legal person who claims to be harmed by the violation of the discrimination law may apply to the Human Rights and Equality Institution established under the Law No. 6701 . However, in case of discrimination other than discrimination based on Article 3, it is a question that it can not apply to the Institution. Furthermore, before applying to the Institution, it is stipulated that the persons should request from the relevant party to correct the application which they claim is contrary to this Law. Stipulating such a condition in the examination of individual applications, which is the fundamental activity to keep the institution functioning, will make it difficult for the individual to apply to the institution, especially if the discrimination is carried out by someone who has a hierarchical relationship with the individual. When the Human Rights and Equality Institution detects discrimination, the sanction imposed is administrative penalty. However, the minimum amount of administrative penalties defined by Law is quite low. There is also the authority of the Institution to convert this penalty to a penalty of warning. It is therefore difficult to argue, that a deterrent sanction mechanism is stipulated in the Law.

Anahtar Kelimeler: Türkiye İnsan Hakları ve Eşitlik Kurumu, ayrımcılığın tanımı, eşitlik ilkesi, ayrımcılık yasağı, 6701 sayılı Türkiye İnsan Hakları ve Eşitlik Kurumu Kanunu

JEL Kodları: K30, K31

\section{GiRiş}

20.04.2016 tarihinde 6701 sayılı Türkiye İnsan Hakları ve Eşitlik Kurumu Kanunu yürürlüğe girmiştir.

Esasen 21.06.2012 tarihli ve 6332 sayılı Türkiye İnsan Hakları Kurumu Kanununu ile insan haklarının korunması ve geliştirilmesi alanında çalışmalar yapmakla görevli bir kurul olan Türkiye İnsan Hakları Kurumu meydana getirilmişti. Ancak Türkiye'nin de taraf olduğu, İşkenceye ve Diğer Zalimane, Gayriinsanî veya Küçültücü Muamele veya Cezaya Karşı Birleşmiş Milletler Sözleşmesine Ek İhtiyari Protokol'de (OPCAT) ceza ve tutukevleri, kamplar, bakım merkezleri gibi yerlerde işkence ve kötü muamele vakalarının yaşanmaması amacıyla bu yerlere yönelik izleme, inceleme, denetleme, değerlendirme ve raporlama faaliyeti yürüten bir ulusal önleme mekanizmasının oluşturulması ya da mevcut insan hakları kuramlarına bu görevin verilmesi öngörülüyordu. Türkiye İnsan Hakları Kurumuna, 09.12.2013 tarihli ve 2013/5711 sayılı Bakanlar Kurulu Kararıyla ulusal önleme mekanizması görevi verilmiş ve Kurumun bu sorumluluğun yüklenmesi, kapasite anlamında güçlendirilmesi ihtiyacını da beraberinde getirmiştir. 6332 sayılı Kanun'u ilga eden 6701 sayılı Kanun'un gerekçesine göre, mevcut Türkiye İnsan Hakları Kurumunun kurumsal kapasitesinin güçlendirilerek etkinliğinin artırılmasının yanı sıra, Kanun'un hazırlanmasındaki diğer hedefler, ayrımcılık yasağı ve eşit muamele ile ilgili temel yasal çerçevenin ve kurumsal yapının düzenlenmesi, işkence ve kötü muameleye karşı ulusal önleme mekanizmasının etkinliğinin ve işlerliğinin artırılmasıdır. Her ne kadar Kanun'un gerekçesinde, aşağıda değineceğimiz Paris Prensipleri'ne atıf yapılmış olsa da, 6 yıl boyunca “Ayrımcılıkla Mücadele ve Eşitlik Kanunu Tasarısı Taslağı”olarak İçişleri Bakanlı̆̆ı'nın sayfasında yer alan tasarı ortadan kaldııımış ve 6701 sayılı Kanun'un hazırlanma sürecinde, sivil toplum kuruluşlarının, derneklerin, vakıfların, baroların ve üniversitelerin görüşünün alınmamış, TBMM İnsan Haklarını İnceleme Komisyonu ile istişare edilmemiştir. Dolayısıyla henüz daha hazırlanma aşamasında, Paris Prensipleri'nin söz konusu kurullar için öngördüğü temel ilkelerden olan çoğulculuk ilkesi ihlal edilmiştir.

6701 sayılı Kanun isminden ötürü bir teşkilat kanunu gibi görünmektedir; ancak Kanun esasen İnsan Hakları ve Eşitlik Kurumu'nun oluşumu, göreve ve yetkilerinin yanı sıra, ayrımcılığa ilişkin kavramsal tanımlar ve ayrımcılığın önlenmesine ilişkin düzenlemeler de içermektedir. Dolayısıyla Kanun'un adı, içeriği konusunda yanıltıcı olması sebebiyle eleştiriye açıktır. Bu çalışmanın ilk bölümünde, 6701 sayılı Kanun'daki ayrımcılık yasağı ile ilgili düzenlemeler, ikinci bölümünde ise Türkiye İnsan Hakları ve Eşitlik Kurumuna ilişkin düzenlemeler çerçevesinde Kanun'un getirdiği yenilikler incelenecektir.

\section{6701 SAYILI KANUN’DA YER VERILEN AYRIMCILIK YASAĞI ILE ILGILI DÜZENLEMELER}

Ayrımcılık yasağına ilişkin gerek uluslararası gerekse karşılaştırmalı hukukta, ayrımcılık temellerini sınırlı sayıda belirtmek ve ucu açık düzenlemeler yapmak şeklinde iki eğilim göze çarpmaktadır. Anayasa'nın "kanunda önünde eşitlik" başlıklı 10. 
maddesi ile 4857 sayılı iş Kanunu'nun "eşit davranma ilkesi" başlıklı 5. maddesinde "benzeri sebeplerle" ibaresine yer verilerek, söz konusu maddelerde yasaklanmış olan ayrımcılık temellerine başka temellerin de dahil edilmesine olanak tanınmıştır (Bakırcı:2017,74). 6701 sayılı Kanun'da ise, Anayasa'dan ve 4857 sayılı Kanun'dan farklı olarak, "ve benzeri" gibi bir ibareye yer verilmeyerek ayrımcılık yasağına esas oluşturan hususlar sınırlı sayıda belirtilmiştir. Kanun'un 3. maddesine göre, herkes, hukuken tanınmış hak ve hürriyetlerden yararlanmada eşittir (f.1). Maddenin 2. fıkrasında bu Kanun kapsamında cinsiyet, ırk, renk, dil, din, inanç, mezhep, felsefi ve siyasi görüş, etnik köken, servet, doğum, medeni hâl, sağlık durumu, engellilik ve yaş temellerine dayalı ayrımcılığın yasak olduğu ifade edilmiştir. Görüldüğü gibi cinsel yönelim madde kapsamına alınmamıştır. LGBT bireylerin toplumda en çok ayrımcılığa ve nefret söylemine maruz kalan gruplar arasında bulunduğu dikkate alındığında, bu hususun büyük bir eksiklik olduğuna şüphe yoktur. Nitekim söz konusu eksiklik, doktrinde (Bakırcı:2017,75) ve AB 2016 ilerleme raporunda da eleştirilmiştir (AB 2016 ilerleme Raporu, s.65).

6701 sayılı Kanunla getirilen en önemli yeniliklerden biri ayrımcılık yasağına ilişkin kavramların tanımlanmasıdır. Kanun'un 4. maddesine göre, bu Kanun kapsamına giren ayrımcılık türleri, ayrı tutma, ayrımcılık talimatı verme ve bu talimatları uygulama, çoklu ayrımcılık, doğrudan ayrımcılık, dolaylı ayrımcılık, işyerinde yıldırma, makul düzenleme yapmama, taciz ve varsayılan temele dayalı ayrımcılıktır. Maddede ayrıca eşit muamele ilkesine uyulması veya ayrımcılığın önlenmesi amacıyla idari ya da adli süreçleri başlatan yahut bu süreçlere katılan kişiler ile bunların temsilcilerinin, bu nedenle maruz kaldıkları olumsuz muamelelerin de ayrımclık teşkil edeceği belirtilmiştir. Kanun'un "tanımlar" başıklı 2. maddesi uyarınca ise, bu Kanun'un uygulanmasında “ayrı tutma” kavramı, kişilerin bu Kanun'da sayılan temellerden biri veya birden fazlası nedeniyle, bir eylem veya eylemsizliğin sonucu olarak diğerlerinden ayrı tutulması durumunu, "ayrımcılık talimatı", bir kişinin kendi nam veya hesabına eylem ve işlemlerde bulunmaya yetkili kıldığı kişilere veya bir kamu görevlisinin diğer kişilere verdiği ayrımcılık yapılmasına yönelik talimatı; "çoklu ayrımcılık", ayrımcı uygulamanın birden fazla ayrımcılık temeli ile ilişkili olması durumunu; "doğrudan ayrımcılık", bir gerçek veya tüzel kişinin, hukuken tanınmış hak ve hürriyetlerden karşılaştırılabilir durumdakilere kıyasla eşit şekilde yararlanmasını bu Kanunda sayılan ayrımcılık temellerine dayanılarak engelleyen veya zorlaştıran her türlü farklı muameleyi; "dolaylı ayrımcılık”, bir gerçek veya tüzel kişinin, görünüşte ayrımcı olmayan her türlü eylem, işlem ve uygulamalar sonucunda, bu Kanun'da sayılan ayrımcılık temelleriyle bağlantılı olarak, hukuken tanınmış hak ve hürriyetlerden yararlanma bakımından nesnel olarak haklılaştırılamayan dezavantajlı bir konuma sokulmasını; "işyerinde yıldırma", bu Kanunda sayılan ayrımcılık temellerine dayanılarak kişiyi işinden soğutmak, dışlamak, bıktırmak amacıyla kasıtlı olarak yapılan eylemleri; "taciz", psikolojik ve cinsel türleri de dâhil olmak üzere bu Kanun'da sayılan temellerden birisine dayanılarak, insan onurunun çiğnenmesi amacını taşıyan veya böyle bir sonucu doğuran yıldırıcı, onur kırıcı, aşağılayıcı veya utandırıcı her türlü davranışı; "makul düzenleme", engellilerin hak ve özgürlüklerini tam ve diğer bireylerle eşit şekilde kullanmasını veya bunlardan yararlanmasını sağlamak üzere belirli bir durumda ihtiyaç duyulan, mali imkânlar nispetinde, ölçülü, gerekli ve uygun değişiklik ve tedbirleri, "varsayılan temele dayalı ayrımcılık" ise, bir gerçek veya tüzel kişinin, bu Kanun'da sayılan ayrımcılık temellerinden birisiyle gerçekte ilgisi olmamasına rağmen, bu temellerden birisini taşıdığı sanılarak hukuken tanınmış hak ve hürriyetlerden yararlanma bakımından ayrımcı muameleye maruz kalmasını ifade etmektedir (Tanımlara ilişkin ayrıntılı inceleme için bakınız: Odyakmaz, Keskin, Deniz : 2016, 736 vd.). Her ne kadar maddede yer verilen tanımlardan önce, "bu Kanun'un uygulanmasında" ibaresi bulunsa da, hukukumuzda ilk defa söz konusu kavramlar pozitif bir düzenleme ile tanımlandığı için, bundan sonra ilgili kavramların içeriği tespit edilirken 6701 sayılı Kanun referans alınacaktır.

6701 sayılı Kanun'da ayrımcılık yasağının kapsamı oldukça geniş tutulmuştur. Kanun, öngörülen istisnalar dışında, hem özel sektördeki hem de kamu sektöründeki ayrımcılık yasağı ihlallerini kapsamakta ve böylelikle bir yandan gerçek ve tüzel kişilerin ayrımcılık yapması yasaklanırken, diğer yandan da ayrımcılığa uğrayan hem gerçek hem tüzel kişiler için koruma sağlanmış bulunmaktadır. Kişiler yönünden ise Kanun, mal ve hizmetlere erişmek isteyenler (m.5/1 ve 3), çeşitli örgütlere katılmak ve olanaklarından yararlanmak isteyenler (m.5/4) ile gerek bağımsız gerekse bağımlı olmak üzere çalışanları (m.6) kapsamaktadır (Bakırcı:2017,72.) Kanun'da çalışma yaşamına ilişkin özel bir düzenleme de getirilmiş ve 6. maddede, "Işsveren veya işveren tarafından yetkilendirilmiş kişi; işverenin çalışanı veya bu amaçla başvuran kişi, uygulamalı iş deneyimi edinmek üzere bir işyerinde bulunan veya bu amaçla başvuran kişi ve herhangi bir sıfatla çalışmak ya da uygulamalı iş deneyimi edinmek üzere işyeri veya iş ile ilgili olarak bilgi edinmek isteyen kişi aleyhine, bilgilenme, başvuru, seçim kriterleri, işe alım şartları ile çalışma ve çalışmanın sona ermesi süreçleri dâhil olmak üzere, işle ilgili süreçlerin hiçbirinde ayrımcılık yapamaz." hükmüne yer verilmiştir. 6071 s. K. m.6/II'ye göre, söz konusu düzenleme, iş ilanı, işyeri, çalışma şartları, mesleki rehberlik, mesleki eğitim ve yeniden eğitimin tüm düzeylerine ve türlerine erişim, meslekte yükselme ve mesleki hiyerarşinin tüm düzeylerine erişim, hizmet içi eğitim, sosyal menfaatler ve benzeri hususları da kapsar. Madde de ilgili düzenlemelerin, 4857 sayılı iş Kanunu kapsamına girmeyen her türlü iş ve iş görme sözleşmeleri ile kamu kurum ve kuruluşlarında istihdam ilişkilerinde de uygulanacağı ifade edilmiştir. Görüldüğü gibi, madde isabetli olarak tabi olduğu kanuna bakmaksızın her türlü iş görme sözleşmeleri ile stajyer ve çırakları da kapsama alacak şekilde düzenlenmiş ve iş ilanı da dahil olmak üzere iş ilişkisinin her sürecinde geçerli olacak şekilde kaleme alınmış ve "benzeri hususları" ibaresine yer verilerek sayılanların örnek teşkil ettiği de ortaya konmuştur. 4857 sayılı iş̧ Kanunu dışındaki iş̧̧ilerle ilgili mevzuatta ayrımcılık yasağıyla ilgili düzenlemeler mevcut bulunmamaktadır. Bu nedenle 6701 sayılı Kanun'un ilgili grubu kapsamasının önemli olduğunu belirtmek gerekir (Bakırcı:2017,73.) .

6701 sayılı Kanun'un eleştiriye en açık maddelerinden biri, ayrımcılığın ileri sürülemeyeceği halleri düzenleyen 7. maddedir. Maddede, istihdam ve serbest meslek alanlarında, zorunlu mesleki gerekliliklerin varlığı hâlinde amaca uygun ve orantılı olan farklı muamele, sadece belli bir cinsiyetin istihdamını zorunlu kılan durumlar, işe kabul ve istihdam sürecinde, hizmetin 
zorunlulukları nedeniyle yaş sınırlarının belirlenmesi ve uygulanması, gereklilik ve amaçla orantılı olması şartıyla yaşa dayalı farklı muamele, çocuk veya özel bir yerde tutulması gereken kişilere yönelik özel tedbirler ve koruma önlemleri, bir dine ait kurumda, din hizmeti veya o dine ilişkin eğitim ve öğretim vermek üzere sadece o dine mensup kişilerin istihdamı, dernek, vakıf, sendika, siyasi parti ve meslek örgütlerinin, ilgili mevzuatlarında veya tüzüklerinde yer alan amaç, ilke ve değerler temelinde üye olacak kişilerde belli şart ve nitelik aramaları, eşitsizlikleri ortadan kaldırmaya yönelik, gerekli, amaca uygun ve orantılı farklı muamele ve vatandaş olmayanların ülkeye giriş ve ikametlerine ilişkin şartlarından ve hukuki statülerinden kaynaklanan farklı muamele durumlarında bu Kanun ayrımcılık iddiasının ileri sürülemeyeceği öngörülmüştür. Doktrinde haklı olarak "sadece belli bir cinsiyetin istihdamını zorunlu kılan durumlar" ibaresinin 4857 sayılı is Kanunu’nda kadın işçiler için öngörülen istisnalardan daha kapsamlı olduğu, bu Kanunun gerisinde kaldığı ve Uluslararası ÇalışmaTeşkilâtının (ILO) 111 no.lu Ayırımcılık Sözleşmesi'ne aykırı olduğu ifade edilmiştir (Odyakmaz, Keskin, Deniz : 2016, s.736). Gerçekten de 4857 sayılı Kanun'da kadın işçilere yer ve su altında çalışma yasağı (m.72), analık hali ile emzirme dönemine ilişkin bazı yasaklar getirilmişken, bu düzenlemeninn geniş yorumlanması ile cinsiyet temelinde yapılan bazı ayrımcılıkları meşrulaştırmak mümkün olacaktır. Bunun yanı sıra, "eşitsizlikleri ortadan kaldırmaya yönelik, gerekli, amaca uygun ve orantılı farklı muamele" ibaresinin yorumu da, kötüniyetli uygulamalara imkan vermeye müsaittir.

\section{3- TÜRKIYE INSAN HAKLARI VE EŞiTLIK KURUMU (TIHEK)}

\subsection{Ulusal İnsan Hakları Kurumları ve TiHEK}

Başlangıçta kamu denetçiliği (ombudsperson) kurumu olmak üzere "ulusal insan hakları kurumları" olarak ifade edilen çeşitli kurumlar, özellikle 1970'li yıllardan itibaren Dünyada hızla yaygınlaşmıştır. Genel olarak, insan haklarının korunması ve yaygınlaştırılması amacına hizmet etmek için kurulmuş daimi ve bağımsız organlar şeklinde tanımlayabileceğimiz (Oğuşgil:2015, 178) ulusal insan hakları kurumları pek çok devlette farklı isimler ve biçimler altında kurulmakta, kimi devletlerde mücadele konularına göre ayrı ayrı, kimi devletlerde ise tek bir çatı altında örgütlenmektedir. Dolayısıyla ulusal insan hakları kurumlarıyla ilgili yeknesak bir yapıdan bahsetmek mümkün değildir. Bununla birlikte, bu kurumların üstlendikleri işlevler hakkında standartlar oluşturmak amacıyla Birleşmiş Milletler (BM) tarafından, 1970'li yıllarda başlayan çalışmalar sonucunda 1993 yılında, "Paris İlkeleri" olarak da anılan "Ulusal Kurumların Statüsü ile illgili ilkeler" kabul edilmiştir. Hukuken bağlayıcı olmayıp tavsiye niteliğinde de olsa, ulusal insan hakları kurumlarının statüleri, sahip olmaları gereken standartlar ve tanımı netleştirilmeye amaçlayan Paris ilkkeleri siyasi bir ağırlığa sahiptir (Bakırcı: 2016, 66-68, Oğuşgil:2015, 177).

Türkiye'de TiHEK dışında, Başbakanlık merkez teşkilatına bağlı bir birim olan İnsan Hakları Başkanlığı, î Ve İlçe İnsan Hakları Kurulları, çeşitli bakanlıkların müsteşarlarından oluşan İnsan Hakları Üst Kurulu, Devlet Bakanına bağlı olarak görev yapan İnsan Hakları Danışma Kurulu, İnsan Hakları Eğitimi On Yılı Ulusal Komitesi, yine başbakanlık Bünyesinde İnsan Hakları İhlal İddialarını İnceleme Heyetleri, TBMM İnsan Haklarını İnceleme Komisyonu, TBMM Kadın Erkek Fırsat Eşitliği Komisyonu, Cezaevleri İzleme Kurulları bulunmaktadır (Detaylı bilgi için bakınız: Odyakmaz, Keskin, Deniz : 2016, 730 vd., Tezcan, Erdem, Sancakdar, Önok:2016,817 vd; Kilim, Şener, Demirbilek: 2014, 283 vd. ). TiHEK'in kurulmasını öngören 6701 sayılı Kanunla birbirleriyle bağlantılı olan, insan haklarının korunması ve geliştirilmesi, ayırımclıkla mücadele ve eşit muamele hakkı, işkence ve kötü muameleye karşı mücadelenin tek bir kurumsal çatı altında toplanması amaçlanmıştır (Odyakmaz, Keskin, Deniz : 2016, 733). TiHEK de, yargısal benzeri yetkilerle donatılmış olması nedeniyle bağlayıcı kararlar alma yetkisi olmayan diğer ulusal mekanizmalardan ayrılmaktadır ve Kurumun, Kanun'un öngördüğü usuller çerçevesinde resen insan hakları ve ayrımcılık yasağı ihlallerini incelemek ve karara bağlamak $(\mathrm{m} .9 / \mathrm{f}$ ve $\mathrm{g})$, ihlale son verilmesi veya mağdura tazminat ödenmesini içeren uzlaştırma (m.18/f.3) ve itiraz yolu açık olmayan 1000 liradan 5000 liraya kadar idari para cezası verme yetkileri mevcuttur (m.25) (Bakırcı: 2016, 69). Öte yandan, 6701 sayılı Kanun'un demokratik ve katılımcı bir zihniyetle yapılmaması, TIHEK ile Kamu Denetçiliği Kurumunun görev ve yetki alanlarında çakışma olması, Kurumların aynı temel konuları savunmaları durumunda yurttaşların benzer konularda hangi kuruma başvuracakları konusunda karışıklık olabileceği, Kurumun yönetim organının üyelerinin seçim usulünün Paris Prensipleri ile çelişmesi, çoğulculuk ve bağımsızlık ilkelerinin göz ardı edilmesi, bazı kavramların tanımının bulunmadığı gibi hususlar sebebiyle 6701 sayılı Kanun ve TiHEK'in oldukça eleştirilmiştir (Odyakmaz, Keskin, Demir:2016, s. 782). Ancak 6701 sayılı Kanun'un 6 maddesinin iptali, için Anayasa Mahkemesinde (AYM) açılan dava, oybilriği ile reddedilmiştir (AYM E. 2012/98, K.2013/92, T. 17.07.2013, http://legalbank.net/belge/aym-e-2012-98-k-2013-92-t-17-07-2013/1376852/, 10.05.2017).

\subsection{Kurumun Görevleri}

6701 sayılı Kanunla, Türkiye İnsan Hakları ve Eşitlik Kurumuna farklı alanlarda pek çok görev verilmiştir. 6701 s. K. m.9 uyarınca Kurumun görevleri şunlardır:

-İnsan haklarının korunmasına, geliştirilmesine, ayrımcılığın önlenmesine ve ihlallerin giderilmesine yönelik çalışmalar yapmak.

- İnsan hakları ve ayrımcılıkla mücadele konularında kitle iletişim araçlarını da kullanarak bilgilendirme ve eğitim yoluyla kamuoyunda duyarlılığı geliştirmek.

-Millî eğitim müfredatında bulunan insan hakları ve ayrımcılık yasağıyla ilgili bölümlerin hazırlanmasına katkıda bulunmak. 
-İnsan haklarının korunması, ayrımcılı̆ın ortadan kaldırılması ve toplumdaki eşitlik anlayışının geliştirilmesine yönelik olarak üniversiteler ile ortaklaşa faaliyetlerde bulunmak, Yükseköğretim Kurulunun eşgüdümünde üniversitelerin insan hakları ve eşitlik ile ilgili bölümlerinin kurulmasına ve insan hakları ve eşitlik öğretimine dair müfredatın belirlenmesine katkıda bulunmak.

-Kamu kurum ve kuruluşlarının meslek öncesi ve meslek içi insan hakları ve eşitlik eğitimi programlarının esaslarııın belirlenmesine ve bu programların yürütülmesine katkıda bulunmak.

-Görev alanıyla ilgili mevzuat çalışmalarını izlemek, değerlendirmek, bunlara ilişkin görüş ve önerilerini ilgili mercilere bildirmek.

-İnsan hakları ihlallerini resen incelemek, araştırmak, karara bağlamak ve sonuçlarını takip etmek.

- Ayrımcılık yasağı ihlallerini resen veya başvuru üzerine incelemek, araştırmak, karara bağlamak ve sonuçlarını takip etmek.

- Ayrımcılık yasağı ihlalleri nedeniyle mağdur olduğu iddiasıyla Kuruma başvuranlara mağduriyetlerinin giderilmesi için kullanabilecekleri idari ve hukuki süreçler konusunda yol göstermek ve başvurularını takip etmelerini sağlamak amacıyla yardımcı olmak.

-İşkence ve kötü muamele ile mücadele etmek ve bu konuda çalışmalar yapmak.

-işsenceye ve Diğer Zalimane, Gayriinsanî veya Küçültücü Muamele veya Cezaya Karşı Birleşmiş Milletler Sözleşmesine Ek intiyari Protokol hükümleri çerçevesinde ulusal önleme mekanizması olarak görev yapmak.

-Özgürlüğünden mahrum bırakılan ya da koruma altına alınan kişilerin ulusal önleme mekanizması kapsamındaki başvurularını incelemek, araştırmak, karara bağlamak ve sonuçlarını takip etmek.

-Özgürlüğünden mahrum bırakılan ya da koruma altına alınan kişilerin bulundukları yerlere haberli veya habersiz düzenli ziyaretler gerçekleştirmek, bu ziyaretlere ilişkin raporları ilgili kurum ve kuruluşlara iletmek, Kurulca gerekli görülmesi durumunda kamuoyuna açıklamak, ceza infaz kurumlan ve tutukevleri izleme kurulları, il ve ilçe insan hakları kurullan ile diğer kişi, kurum ve kuruluşlann bu gibi yerlere gerçekleştirdikleri ziyaretlere ilişkin raporları incelemek ve değerlendirmek.

-Cumhurbaşkanlığına, Türkiye Büyük Millet Meclisi Başkanlığına ve Başbakanlığa sunulmak üzere, insan haklarının korunması ve geliştirilmesi, işkence ve kötü muameleyle mücadele ve ayrımcılıkla mücadele alanlarında yıllık raporlar hazırlamak.

-Kamuoyunu bilgilendirmek, düzenli yıllık raporlar dışında, gerek görüldüğünde görev alanına ilişkin özel raporlar yayımlamak.

-İnsan hakları ve ayrımcılıkla mücadele alanındaki uluslararası gelişmeleri izlemek ve değerlendirmek, alanındaki uluslararası kuruluşlarla ilgili mevzuat dâhilinde işbirliği yapmak.

-İnsan haklarının korunması ve ayrımcılıkla mücadele kapsamında faaliyet yürüten kamu kurum ve kuruluşları, sivil toplum kuruluşları, meslek kuruluşları ve üniversitelerle işbirliği yapmak.

-Türkiye'nin taraf olduğu uluslararası insan hakları sözleşmelerinin uygulanmasını izlemek, bu sözleşmeler uyarınca kurulan inceleme, izleme ve denetleme mekanizmalarına Devletin sunmakla yükümlü olduğu raporların hazırlanması sürecinde, ilgili sivil toplum kuruluşlarından da yararlanmak suretiyle görüş bildirmek, bu raporların sunulacağı uluslararası toplantılara temsilci göndererek katılmak.

- Kanunlarla verilen diğer görevleri yapmak.

\subsection{Kurumun Teşkilat Yapısı ve Nitelikleri}

Paris Prensipleri ulusal kurumlar için temel olarak bağımsızlık ve yetki güvencesi öngörmektedir. Bağımsızlığın sağlanması için, Kurumun yasal temelde kurulması, çoğulcu yapıda meydana gelmesi, kendi bütçesine ve personeline sahip olması, kendi çalışma koşullarını kendi belirlemesi gibi organik bağımsızlığın yanı sıra, finansal ve işlevsel özerkliğe sahip olması da önemlidir (Eren:2016, 79; Oğuşgil:2015, 179). Yetki güvencesi bağlamında ise, ulusal kurumlar faaliyetlerini etkili bir şekilde gerçekleştirmek için, anayasa veya yasada açık ve ayrıntılı bir şekilde geniş bir yetki güvencesiyle donatılmalıdır. Bu çerçevede, kendisine iletilen şikayet ve dilekçeleri kabul edip inceleme ve insan haklarının ihlal edildiği veya edilme ihtimali olan yerlere ziyaret gerçekleştirme, gerekli gördüğünde her türlü bir bilgi ve belgeyi edinme ve bütün kişileri dinleme, raporlar hazırlama ile insan haklarına yönelik yasa ve uygulamalarla ilgili olarak hükümet ve parlamento dahil olmak üzere ilgili kurumlara görüş ve tavsiyede bulunma yetkilerine kurumların sahip olması gereken yetkilerdir (Oğuşgil:2015, 179).

6701 sayılı Kanun'un 10. maddesi uyarınca, Kurumun karar organı Türkiye İnsan Hakları ve Eşitlik Kuruludur. Her ne kadar 6701 sayılı Kanun'da 8. maddenin yanı sıra, Kurumun'un bağımsızlığını sağlamaya yönelik, m.10/I'deki “Kurul, bu Kanunla ve diğer mevzuatla verilen görev ve yetkilerini kendi sorumluluğu altında, bağımsız olarak yerine getirir ve kullanır. Görev alanına giren konularla ilgili olarak hiçbir organ, makam, merci veya kişi, Kurula emir ve talimat veremez, tavsiye ve telkinde bulunamaz.", m.12/f.1 ve f.2'deki "Kurul, Başkanın çağrısı üzerine toplanır...Toplantı gündemi Başkan tarafından 
hazırlanarak...", m.13/f.2-ç'deki "Başkan...Kurum personelini atamak" gibi hükümler bulunsa da, bağımsızlığın altyapısı ve şartları oluşturulmadan söz konusu düzenlemeler uygulamada bir anlam ifade etmemektedir (Eren:2016, 80). Zira 6701 sayılı Kanun'un eleştiriye en açık düzenlemelerinden biri Kurumun karar organı olan Türkiye İnsan Hakları ve Eşitlik Kurulunun oluşumuna ilişkindir. 11 üyeden oluşan Kurulun 8 üyesi Bakanlar Kurulu, 3 üyesi ise Cumhurbaşkanı tarafından seçilmektedir (m.10/f.2). Hükümde, Bakanlar Kurulunca seçilecek 1 üyenin Yükseköğretim Kurulu tarafından insan hakları alanında çalışmalar yapan öğretim üyelerinden önerilecek iki aday arasından; 7 üyenin de insan hakları alanında çalışmalar yapan sivil toplum kuruluşları, sendikalar, sosyal ve mesleki kuruluşlar, akademisyenler, avukatlar, görsel ve yazılı basın mensupları ve alan uzmanlarının göstereceği adaylar veya üyelik başvurusu yapanlar arasından belirleneceği ifade edilmiştir. Cumhurbaşkanı tarafından seçilecek üyeler açısından herhangi bir düzenleme öngörülmemiştir. Seçim sürecinin temel noktaları dahi Kanun'da yer almamaktadır. Bakanlar Kurulu tarafından seçilecek üyeler için getirilen "insan hakları alanında çalışmalar yapmak" ifadesi ise, oldukça belirsizdir. Bütün üyeleri yürütme erki tarafından belirlenen Kurulun yürütmeden nasıl bağımsız hareket edeceği ve özellikle bizzat yürütme erki tarafından gerçekleştirilen hak ihlallerine karşı nasıl tarafsız davranacağı soru işaretidir. Paris Prensipleri'nin "Oluşturulma Biçimleri ve Bağımsızlık ile Çoğulculuk Güvenceleri" maddesi uyarınca, ulusal kuruluşların oluşturulması ve üyelerinin seçimle veya başka bir yoldan belirlenmesi, insan haklarının geliştirilmesi ve korunmasıyla ilgili (sivil) toplum güçlerinin çoğulcu bir biçimde temsil edilmesini sağlayacak gerekli bütün güvencelerin varolduğunu gösteren bir usulle yapılmalıdır. Kanun'da öngörülen usulün bu nitelikte olmadığı açıktır. Maddede, bu hususun özellikle,

(a) Insan hakları ve ırk ayrımcılığına karşı mücadeleyle ilgili sivil toplum kuruluşları, sendikalar ve örneğin hukukçu, hekim, gazeteci ve bilim insanlarını bir araya getiren sosyal-mesleki kuruluşların,

(b) Din ve felsefi düşünce akımlarının,

(c) Üniversitelerin ve nitelikli uzmanların,

(d) Parlamentonun,

(e) (ancak istişari mahiyette katılmak koşuluyla) yönetimin temsilcileriyle etkin bir işbirliğine imkan veren yetkilerle veya bu temsilcilerin bu kuruluşlara katılımıyla gerçekleştirilebileceği ifade edilmiştir. Çoğulculuğu sağlamak için, Kurumun karar organı olan Türkiye İnsan Hakları ve Eşitlik Kurulu üyelerinin br kısmının da yasama organı, barolar, sivil toplum örgütleri veya muhalif temsilciler tarafından seçimine imkan verilecek bir usul belirlenmelidir (Eren:2016, 80). Özellikle toplumda en çok ayrımcılığa maruz kalan LGBT bireylerin, etnik ve dinsel azınlıklara mensup bireylerin ve kadın hakları alanında çalışan sivil toplum örgütlerinin bu seçimde yer alabilmesi gerekir. 6332 sayılı Kanunla kurulmuş bulunan "İnsan Hakları Kurumu”nu oluşturan 11 üyeden iki üye üniversiteler ve barolar tarafından seçilmekteyken, TiHEK'in karar organı olan kurulun üyelerinin seçiminde bu hususa dahi yer verilmemiştir.

Paris Prensipleri'nin iligli maddesinde ayrıca ulusal kuruluşların, çalışmalarını gerektiği gibi yürütebilmeleri için, uygun bir altyapıya, özellikle de yeterli mali kaynaklara sahip olması gerekirir. Madde uyarınca, bu kaynaklar kendi personelini istihdam etmeyi ve kendi mekanlarına sahip olmayı da sağlamalıdır. Böylelikle ilgili kuruluşlar, hükümetten bağımsız olabilecek ve bu bağımsızlı̆̆ı tehlikeye düşürecek mali bir kontrole tabi olmayacaklardır. 6701 sayılı Kanun'un 23. maddesinde Kurumun gelirlerinin genel bütçeden yapılacak hazine yardımları, Kuruma ait taşınır ve taşınmazlardan elde edilen gelirler, gelirlerinin değerlendirilmesinden elde edilen gelirler ve diğer gelirlerden oluştuğu ifade edilmiştir; ancak 2016 yılına ilişkin $A B$ ilerleme raporunda da belirtildiği gibi, Kurumun Paris illkeleri ve AB müktesebatı ile uyumlu olarak, işlevsel, yapısal ve mali bağımsızlığı sağlanmamıştır (AB 2016 İlerleme Raporu 2016, s.76). 2017 yılı Bütçe Kanunu'na göre, 2017 yılında TiHEK'e tahsis edilen bütçe 6.844.000 TL.dir. Bunun 2.082.000 TL'si personel giderleri olarak ayrılmıştır (2017 yılı Merkezi Yönetim Bütçe Kanunu, II sayılı cetvel, RG No. 29928 mükerrer, 24.12.2016) . Örnek teşkil etmesi açısından belirtmek gerekirse, Radyo ve Televizyon Üst Kuruluna 2017 yılında tahsis edilen bütçe 181.000 .000 TL olup bunun 125.668.000 TL'si personel giderleri içindir (2017 yılı Merkezi Yönetim Bütçe Kanunu III sayılı cetvel). Tüm Türkiye'de ayrımcılık, işkence ve kötü muamele ile mücadele etmek üzere oluşturulan Kuruma personel giderleri için ayrılan bütçe, Radyo ve Televizyon Üst Kurulunun personel giderleri için tahsis edilen bütçenin yaklaşık altmışta biri kadardır. Bu bağlamda Kurumun ciddi bir alt yapı ve iş gücü eksikliği yaşayacağı açıktır. Nitekim Kurum’a 150 kişilik kadro tahsis edilmiştir.

6701 sayılı Kanun'da Kurumun idari özerkliğine gölge düşüren maddeler de mevcuttur. 6701 sayılı Kanun m.14/f.5 uyarınca, gerek görülmesi hâlinde, Kurumun teklifi üzerine Bakanlar Kurulu kararıyla Kuruma bağlı bürolar kurulabilir. Görüldüğü gibi, Kurum'a doğrudan büro açma imkanı verilmeyerek bu yetki Bakanlar Kuruluna bırakılmıştır. Bunun yanı sıra, 6701 sayılı Kanun m.14/f.6'ya göre, "Hizmet birimleri ve büroların çalışma usul ve esasları, bu Kanunda belirtilen faaliyet alanı, görev ve yetkilerine uygun olarak Kurumun teklifi üzerine Bakanlar Kurulu kararıla yürürlüğe konulan yönetmelikle belirlenir." Dolayısıyla Kurum, kendine bağlı birimlerin faaliyetine ilişkin yönetmeliği dahi kendisi hazırlayamamaktadır. Söz konusu hükümler Kurum üzerindeki idari vesayete işaret etmektedir (Eren:2016, 83). Nitekim 6701 sayılı Kanun'un 8. maddesinde Türkiye İnsan Hakları ve Eşitlik Kurumunun "Başbakanlıkla" ilişkili olduğu ifade edilmiştir. Kanun'a karşı açılan iptal davasında, Kurumun ilişkisinin TBMM ile olmaması, Anayasanın özünü oluşturan insan hakları kavramına ve bu kavrama dayalı denetime açıkça aykırı olduğu ifade edilmiştir; ancak AYM iptal istemini reddetmiştir.

\subsection{Kuruma Bireysel Başvuru}


6701 sayılı Kanun'un 17. maddesine göre, ayrımcılık yasağı ihlalinden zarar gördüğü iddiasında bulunan her gerçek ve tüzel kişi 6701 sayılı Kanun çerçevesinde oluşturulan İnsan Hakları ve Eşitlik Kurumu'na başvurabilir. Kuruma başvuru, illerde valilikler, ilçelerde kaymakamlıklar aracılığıyla da yapılabilir. Başvuru hakkının etkin bir şekilde kullanılmasına hiçbir surette engel olunamaz. Başvurulardan herhangi bir ücret alınmaz.

6701 sayılı Kanun'da, TiHEK'e başvurmadan önce, kişilerin, bu Kanun'a aykırı olduğunu iddia ettikleri uygulamanın düzeltilmesini ilgili taraftan talep etmesi gerektiği hükme bağlanmıştır. 6701 sayılı Kanun m.17/5 uyarınca da, "4857 sayılı Kanunun 5. maddesi kapsamına giren ayrımcılık iddialarına ilişkin başvurular, 4857 sayılı Kanun ve ilgili mevzuatında belirlenen şikâyet usulleri izlendikten sonra herhangi bir yaptırım kararı alınmadığı hâllerde yapılabilir". Dolayısıyla 4857 sayılı İş Kanunu'nun 5. maddesinin kapsamına giren ayrımcılık iddialarıyla ilgili önce yargı yoluna başvurulacak ve ancak yargı tarafından herhangi bir yaptırım kararı alınmadığı hâllerde Kurum'a başvurulabilecektir. Kurumu gerçekten işlevsel kılacak temel faaliyet olan bireysel başvuruların incelenmesinde bu koşulların öngörülmesi, özellikle ayrımcılı̆ın ilgilinin hiyerarşik ilişki içerisinde bulunduğu biri tarafından gerçekleştirilmesi halinde Kuruma başvurmasını oldukça güçleştirecektir.

Kurum'un görev ve yetkilerine ilişkin hükümlerde genel olarak "insan hakları" ve "ayrımcılık" ibareleri kullanılsa da, yukarıda yer verdiğimiz üzere, gerek 3. maddenin lafzı, gerekse tanımlara ilişkin 2. maddede ayrı tutma, doğrudan ayrımcılık, dolaylı ayrımcılık, işyerinde yıldırma, taciz ve varsayılan temele dayalı ayrımcılık kavramlarında "bu Kanunda sayılan ayrımcılık temelleri" ifadelerine yer verilmesi sebebiyle, Kanun'da sınırı sayıda yer verilen ayrımclık temelleri dışında bir temele, misal olarak cinsel yönelim veya sendikal faaliyete dayalı ayrımcılık halinde Kurum'a başvurmak mümkün değildir. Nitekim Kanun'un gerekçesinde de: "Ayrımcılığın konusu, "hukuken tanınmış hak ve hürriyetlerden yararlanma" olarak belirlenirken, ayrımcılığın temelleri de "cinsiyet, ırk, renk, dil, din, inanç, felsefi ve siyasi görüş, etnik köken, servet, doğum, medeni hal, sağlık durumu, engellilik, yaş" şeklinde düzenlenmekte, böylece hak ve hürriyetlerden yararlanmayı sayılan temellere dayalı bir davranış ve uygulama ile hukuka aykırı şekilde engellemenin ayrımcılık oluşturacağı hükme bağlanmaktadır." ifadesine yer verilmiştir.

İnsan Hakları ve Eşitlik Kurumu'nun ayrımcılık yapıldığını tespit etmesi halinde uygulayacağı yaptırım idari para cezasıdır; ancak Kanun'da idari para cezalarının asgari miktarı oldukça düşük belirlenmiştir. Ayrıca Kurumun söz konusu cezayı uyarı cezasına dönüştürme yetkisi de mevcuttur. Dolayısıyla Kanun'da caydırıcı bir yaptırım mekanizması öngörüldüğünü ileri sürmek güçtür.

\subsection{Fransa Örneği: "Hakların Savunucu"}

Hakların Savuncusu (Le défenseur des droits) kurumu, temelde hakların ve özgürlüklerin korunmasında görev yapan ve önceden birbirinden bağımsız olan, 4 farklı kurumun aynı çatı altında toplanmasıyla oluşturulmuştur. Bu kurumlardan esas olarak ayrımcılıkla mücadele eden kurum, Ayrımcılığa Karşı ve Eşitlik İçin Mücadele Yüksek Kurumu'ydu (Chevallier:2011, p.434). Söz konusu Kurumların aynı çatı altında birleştirilmesindeki amaç, hakların korunmasında daha rasyonel bir sistem oluşturmak ve bu amacı güden kurumlara başvuruları uyumlu hale getirmektir (Cluzel-Métayer:2011, p.448). Kurumun temel misyonları bireysel başvurular aracılı̆ııla hakları korumak ile haklara erişim ve eşitliğin teşvik edilmesidir (Leconte:2016, p.61).

Hakların Savunucusu, tamamen özerk bir kurumdur. Bu özerklik her seyden mali özerkliği içermektedir. Kurum'un harcamaları hiçbir onay mekanizmasına tabi olmayıp sadece Sayıştay tarafından sonradan gerçekleştirilen bir denetime tabidir. Kurumun bütçesi bütçe kanunu ile belirlenmekle birlikte, bu bütçe üzerinde özerkliğe sahiptir. Kurum'un iç işleyişi ve görev dağımı kendi çıkardığı yönetmelikle düzenlenmekte, kurum personeli yine Kurum tarafından atanmaktadır(Chevallier:2011, p.434). Kurum taşra teşkilatına sahiptir ve Fransa'nın genelinde 450 delege ve 230 memur Kurum bünyesinde faaliyet göstermektedir (Leconte:2016, p.61). Kurumun bütçesi 27436842 Euro'dur (http://www.defenseurdesdroits.fr/fr/rapport-annuel-dactivite-2015/finances-et-ressources-humaines, 10.05.2017).

Hakların Savunucusuna başvurmak isteyenlerin ücret ödemesi gerekmediği gibi, bu başvuruyu doğrudan yapmaları da mümkündür. Başvuruda vatandaşlık koşulu aranmamış olup yabancılar da Kurum'a başvurabilir. Bunun yanı sıra, 5 yıldan fazla süredir faaliyet gösteren ve tüzüklerinde başvuru konusuyla alakalı amaçları olan derneklerin de başvuru yapması mümkündür. Keza bazı kamu otoritelerine de belirli hususlar için başvuru hakkı tanınmıştır (Cluzel-Métayer:2011, p.449). Kurum kendisine yapılan başvurular çerçevesinde, uzlaşma prosedürü işletebilmekte, bireysel yahut genel tavsiye kararları verebilmekte, kanunlar için reform önerileri getirebilmekte ve davalarda görüşünü açıklayabilmektedir. 2016 yılı itibariyle bu görüşlerin \%60'dan fazla hakimler tarafından dikkate alınmış, uzlaşma kapsamındaki faaliyetlerinin de \%80'den fazlası başarıya ulaşmıştır(Leconte:2016, p.61). 2015 yılında Hakların Savunucusuna toplam 138.596 başvuru yapılmıştır (http://www.vie-publique.fr/actualite/alaune/rapport-2016-du-defenseur-droits-activite-hausse-8-8.html, 10.05.2017).

\section{SONUÇ}

6701 sayılı Kanun'un getirdiği en temel yenilik, ayrımcılığa ilişkin kavramların tanımlanmasıdır. Hukukumuzda ilk defa söz konusu kavramlara ilişkin tanımlamalar pozitif dayanak kazanmıştır. Her ne kadar Kanun'un gerekçesinde 6701 sayılı Kanunla mevcut Türkiye İnsan Hakları Kurumunun kurumsal kapasitesinin güçlendirilerek etkinliğinin artırımasının yanı sıra, ayrımcılık yasağı ve eşit muamele ile ilgili temel yasal çerçevenin ve kurumsal yapının düzenlenmesi ile işkence ve kötü muameleye karşı ulusal önleme mekanizmasının etkinliğinin ve işlerliğinin artırılması amaçlandığı ifade edilse de, Kurum'un 
söz konusu amaçlara ulaşmaya elverişli ne organizasyonel yapısı ne de mali özerkliği mevcuttur. Keza Kurumun karar organının tamamen yürütme tarafından seçilmesi de, söz konusu hedeflerin hayata geçirilmesinde başat olan Kurumun bağımsızlığına gölge düşürmektedir. Bunun yanı sıra, ayrımcılığa maruz kaldığı iddiası ile Kuruma başvurmak isteyenlerin, Kuruma başvurmadan önce, bu Kanun'a aykırı olduğunu iddia ettikleri uygulamanın düzeltilmesini ilgili taraftan talep etmesi gerektiğinin hükme bağlanması, Kurumun gerçekten işlevsel kılacak temel faaliyet olan bireysel başvuruların önünde büyük bir engeldir. Kanun'da ayrımcılık yasağına ilişkin istisnaların geniş tutulması, ayrımcılığa temel teşkil eden hususların sınırlı sayıda olması ve yeterli ölçüde caydırıcı yaptırımlar öngörülmemesi de, 6701 sayılı Kanun'u faydasız kılmaktadır.

\section{KAYNAKLAR}

Bakırcı, K. (2017). Eşitlik Kurulu Kanunu ile Anayasa ve Iş Kanunu'nun Illgili Hükümleri Üzerine Bir Değerlendirme, Emeğin Kurultayı 2, İstanbul, s. 65-75.

Chevallier, J. (2011), “Le Défenseur des droits: unité ou diversité?”, Revue française d’administration publique, 2011/3 (no. 139), p.433-445.

Cluzel-Métayer, L. (2011), "Réflexion a propos de la saisine du Défenseur des droits", ?", Revue française d'administration publique, 2011/3 (no. 139), p.447-460.

Eren, H. (2016). Türkiye İnsan Hakları ve Eşitlik Kurumu, 2016.

Ergüzeloğlu-Kilim, E., Şener, M., Demirbilek-Hülagu, F. (2014) "il İnsan Hakları Kurullarında Sosyal Haklar: Mersin Örneği” Sosyal Adalet İçin İnsan Hakları Sosyal Haklar (içinde) Ed. Kıvılcım Akkoyunlu Ertan, Filiz Kartal, Yeliz Şanlı Atay, TODAiE Yayını, Ankara, s. 283-302.

Karcı, M. Ş., Küçükcan, B. (2016) , “Türkiye’de Kamu Yönetiminin Hak Arama Kurumları Yoluyla Denetimi”, C.Ü. İktisadi ve İdari Bilimler Dergisi, Cilt 17, Sayı 1,

Leconte, V. (2016), “L'intervention du Défenseur des droits en matiere de protection sociale des femmes", Regards, 2016/2(No.50), p.61-74.

Odyakmaz, Z., Keskin, B., Deniz, Y. (2016). "6701 Sayılı Türkiye İnsan Hakları Ve Eşitlik Kurumu Kanunu Üzerine Bir Değerlendirme-I”, Uyusmazlik Mahkemesi Dergisi, Sayı 7, s.721-761.

Oğuşgil, V. A. (2015), “Avrupa Birliği Yolunda Türkiye İnsan Hakları Kurumu'nun Birleşmiş Milletler Paris Prensipleri Işığında Değerlendirilmesi", bilig Türk Dünyası Sosyal Bilimler Dergisi, Sayı 74, s.175-198.

Tezcan, D., Erdem M., R., Sancakdar, O., Önok, R., M.(2016), İnsan Hakları El Kitabı, 6. Bası.

Avrupa Komisyonu, 2016 Türkiye Raporu, http://www.ab.gov.tr/files/5\%20Ekim/son 2016 ilerleme raporu tr.pdf, 10.05.2017. 